\title{
Effects of Psycho - Educational Program About Spirituality on The Quality of Life Among Hospitalized Psychiatric Patients
}

Eslam Mohamed Gado: Psychiatric and Mental Health Nursing, Faculty of Nursing, Tanta University

Ikbal Mohamed El Shafie: Professor of - Community Health Nursing, Faculty of Nursing Tanta University

Hala Ahmed El Sayes :Lecturer of pschatric and Mental Health Nursing Faculty of Nursing, Tanta University

Ehab Sayed Ramadan : Professor of Neuro - Psychiatry, Faculty of Medicine, Tanta University

\begin{abstract}
Spirituality affects mental health in a positive way and creates an environment conducive for personal well being. Spirituality is being referred to one of the forgotten dimensions of personal well being and mental health care. It is often described as a mental platform, where one can meet their true self. It is considered a sacred realm of human and self experience. Aim of the Study : to determine the impact of psycho-educational program about spirituality on the quality of life among hospitalized psychiatric patients. Study design : A quasi experimental design was utilized for this study. Setting : The study was conducted at Tanta mental health hospital. Subjects : The subjects of this study consisted of 50 hospitalized psychiatric inpatients, they were fulfilling the following inclusion criteria ; adult aged from 18 to 63 years, psychotic patient not having mystical experiences, able to communicate relevantly and willing to participate in the study. Tools: Three tools were used to collect data A structured Interview Schedule to collect data regarding socio demographic and clinical characteristics of the studied patients, Daily Spiritual Experience Scale and WHO Quality of life instrument. Results : showed that there were significant statistically positive correlation between the total score of quality of life and total score of spirituality among the studied patients pre, immediately, one month and three months post application of the program. The study concluded : The use of spiritual program have a positive effects on quality of life of hospitalized psychotic patients . Recommendations : Awareness and training programs about importance of spirituality for mentally ill patients should be develop and conducted for all psychiatric nurses to participate in the provision of spiritual care .
\end{abstract}

Key wards : Spirituality, Quality of Life, Psychiatric Patient, Mental Illness 


\section{Introduction:}

Spirituality is a core element of our inner world that has no boundaries and certain rules, but built on individual choice. It is the way of validation of the unknown through various religious circles. Spirituality gives people a sense of freedom, the power to live and be spiritually strong person. Moreover, it helps to find a deeper meaning of life, realize obvious things and break the walls of inner conflicts ${ }^{(4) .}$

Spirituality has been defined as the beliefs and practices that develop based on personal values and ideology of the meaning and purpose of life. It refers to the belief that there is a power or powers outside one's own that transcend understanding ${ }^{(5)}$. It has been stated that there are three dimensions of spirituality . These are : making personal meaning out of situations ,coming to an understanding of self and appreciating the importance of connections with others ${ }^{(6)}$.

Spirituality is a client's belief about life, health, illness, death and one's relationship to the universe . It differs from religion, which is an organized systems of beliefs about one or more knowing forces that govern the universe and offer guidelines for living in harmony with universe and others. Spirituality is not an individual creation, it is shaped by larger social circumstances and by the beliefs and values of the wider culture ${ }^{(7)}$.

Recent years have seen an increase in scientific interest in the relationship between religion and spirituality and mental health. This interest has demonstrated beneficial effects in the lives of the religious people. Better mental health, greater well being, higher quality of life, and lower rates of depression, anxiety, and suicide have all been reported among more religious individuals ${ }^{(1,2)}$. However, there is a growing body of research demonstrating that there is also a negative side to religion, and that religiously based struggles can be a source of distress for many patients. This dual nature of religion and spirituality in the lives of psychiatric patients demands increased awareness of the religious aspects of patients' lives, as well as resources available to assist those who are struggling ${ }^{(3)}$. 
Currently, nurses are not well prepared to deal with psychiatric clients' spiritual concerns . Psychiatric nursing curricula and texts devote little content to spirituality. Andrews and Boyle ( 2003 ), discuss several reasons why nurses fail to provide spiritual care to culturally diverse clients . They state the nurse may view religious and spiritual needs as a private matter between the client and his or her creator, deny the existence of spiritual needs or feel uncomfortable about one's own religious beliefs, lack of knowledge about the religious beliefs or spirituality of others, mistake spiritual needs for psychological needs, and believe that the spiritual needs of clients are the responsibility of a family or leader, yet clients clearly want this aspect of their lives to be considered in their care ${ }^{(8)}$.

Koening ( 2007 ), reminds nurses that they should do five things regarding spiritual care ; take a spiritual history, support and show respect for the patient's beliefs ; pray with the patient if the nurse is comfortable doing so and if the patient wants and requests it ; provide spiritual care by being kinds, gentle, sensitive and compassionate, and refer to religious man ${ }^{(9)}$.
Quality of life (QOL) has become an increasingly important concept in assessing clinical change in persons with severe and persistent mental illness. The concept of QOL has progressively shifted from a strictly sociological and objective prospective to a psychosocial prospective in which the individual's sense of wellbeing becomes a primary dimension of QOL. The emphasis of the current approach on subjectivity about satisfaction with life as well as on the individual's perception of his / her daily functioning is more related to the happiness and psychological well-being than to the social indicators of traditional research. QOL has subjective and objective components. The subjective component refers to "wellbeing," "happiness" or "life satisfaction," whereas the objective component refers to aspects of environment and social functioning ${ }^{(10)}$.

Recently , various bio- psycho- social factors have been identified in relation to quality of life for people with mental illness, but the role of spiritual factor on it has been relatively neglected . Little research has been done on the effects of spirituality on quality of life for people with severe mental illness ${ }^{(5)}$. Research findings also have been shown that 
spirituality and religion can enhance individuals' quality of life by positively contributing to greater life satisfaction, happiness, positive affect, morale and hope ${ }^{(11)}$.

Some people express spirituality by participating in an organized religious community and by adhering to a set of rules of behavior for example, the person renews spirituality through experiencing the beauty of nature, the use of prayer , meditation, fasting, belonging to religious literature, and listening to inspiring music Others express spirituality through. forgiveness , worship and rituals , fellowship and altruistic service, and journal writing ${ }^{(12)}$. people suffering from various mental health problems such as depression, anxiety, stress benefits from spirituality ${ }^{(13)}$.

Therefore, this study aims to determine the impact of implementation of psycho educational program about spirituality on quality of life among hospitalized psychiatric patients .

\section{Aim of the study II}

\section{The aim of this study was to :}

Determine the impact of psychoeducational program about spirituality on the quality of life among hospitalized psychiatric patients.

\section{Research Hypothesis:}

Psychiatric patients may improve their perception about their quality of life. This can be achieved through implementation of psycho-educational program about spirituality.

\section{Materials and Method}

\section{Research design}

A quasi - experimental design was utilized for this study

\section{Setting:}

The study was conducted at Tanta Mental Health Hospital affiliated to the Ministry of Health and population mental health care services to Gharbya, Menofia and Kafr El Sheikh governorates .

\section{Subjects:}

The subjects of this study consisted of 50 hospitalized psychiatric inpatients .They were selected according to the following criteria : Adult aged from 18 to 63 years, both sexes psychotic patient not having mystical experiences able to communicate relevantly and willing and agree to participate in the study .

\section{Tools of data collection:}

The data of this study was collected by using three tools : 
Tool I : A structured Interview

\section{Schedule}

It was developed by the researcher, it comprise of two parts :-

part (1) : Bio- Socio Demographic Characteristics Data of the studied patients It include ; age , sex , marital status, residence, living accommodation educational level, occupation and income part (2) : Clinical Characteristics Data of the Studied Patients It include ; diagnosis, the duration of illness, number

of previous hospitalization and date of admission .

\section{Tool II : Daily Spiritual Experience Scale ( DSES)}

The scale was developed by Underwood (2002) (14) , to assess the spirituality experience of participants . It consisted of 16 items, self - report measure of spiritual experience. The implemented toll consisted of 15 statements . The researcher deleted item 12 ( I feel thankful for my blessings ), as it was difficult for the patient to understand and respond , for the first 14 items of the scale, each item measured on a 3 point Likert - type scale ranging from ( $1=$ Every day , $2=$ some days, $\quad 3=$ Once in a while or
Never ). Item 15 was measured on a $4-$ point scale ranging from ( $1=$ Not close at all , 2= Some what close , 3= Very close , 4= As close as possible ). The total score was 46 points which result from multiplying total number of questions, and then the result was divided by 100 to be converted into percentage. The total score of patients' spirituality was calculated and classified as follows : Less than $50 \%$ had low spirituality experience , $50 \%-70 \%$ had moderate spirituality experience and more than $70 \%$ had high spirituality experience

Tool III : WHO Quality of life instrument (WHO QOL- BREF )

This tool was developed by the WHO QOL Group (2004) ${ }^{(15) .}$ The WHO QOL Bref is a Interview report consists of 26 items that measure overall quality of life as well as four specific quality of life domains ; Physical health domains includes ; 7 items, Psychological domains includes ; 6 items , Social relationships domains and Environmental domains includes ; 8 items. Two other items measure overall QOL and general health .The patients were asked to respond to these questions with only one correct response for each 
question . Responses were rated originally on 5 point liker scale. For the purpose of this study, responses to become more easy for the patients to understand items were rated on a 3 - point likert scale ; ranging from ( $1=$ very Poor , $2=$ Neither poor nor good , $3=$ Very good ), 3 indicates high score and 1 indicates low score. The total score was 78 which result from multiplying total number of questions , and then the result is divide by 100 to be converted into percentage. The total score of patients' quality of life was calculated and classified as follows : - Less than $50 \%$ had low quality of life , $50 \%-70 \%$ had moderate quality of life and more than 70 $\%$ had high quality of life .

\section{Method}

- An Official permission to conduct the study was obtained from the Faculty of Nursing to the responsible authorities (The Head of Tanta Mental Health Hospital) . ethical considerations were protected as a written Consent was obtained and patient's privacy and data confidentiality was assured. Tool I (socio-demographic and clinical data sheet) was developed by the researcher, after a thorough review of related literature. Tool II and Tool III were translated into Arabic language by the researcher . Tool II and III were tested for face and content validity by a jury composed of a group of five experts in the psychiatric field to examine validity of the study tools. The pilot study was conducted on 10 patients out of the proposed sample after taking their approval to test the applicability and feasibility of the study tools before embarking in the field of work, after its implementation and according to its result , the necessary modifications were done . Tool II and tool III were tested for reliability by administering it to 10 patients using Cronbach's alpha (a) . The reliability of tool II is also found to be high , and the Cronbach's alpha (a) of the DSES is 0.93 . Reliability estimates based on Cronbach's alpha is high for the total WHOQOL- BREF scale

$(\alpha$ $=.93$ ). Also , reliability estimates for physical health domain subscale $(\alpha=.74)$ ; psychological domain subscale ( $\alpha=.87$ ) ; social domain subscale $(\alpha=.70)$, and environmental domain subscale ( $\alpha=.80$ ) are all satisfactory .

Actual study was divided into four phases:

Assessment phase ; the researcher reviewed all psychiatric in patients' 
records in order to select those who meet inclusion criteria, the selected patients were interviewed for a pre-test using socio- demographic clinical data sheet, Daily Spiritual Experience Scale ( DSES) , and WHO Quality of life instrument (WHO QOL- BREF) . Each interview lasted for $30-45$ minutes, assessment phase took 4 weeks (3days / week ) Program development phase ; the researcher designed a spiritual psycho educational program based on data obtained from the patients in the assessment phase and literature review (15-20). The researcher prepared essential materials for conducting the program such as drawing papers, different size of papers for drawing and painting, water colors, pens, pencils, brushes, books as religious books and holly Quran, colorful magazines and laptops . The study subjects were divided into 10 groups, each group attended a total of 9 sessions, and each group involved 5 patient. Time of each session ranged from 1-2 hours according to the session activities. Sessions were scheduled as 3 session per week. The duration of program implementation for each group was 3 weeks. Place for application of the session : Activity hall in second floor at Tanta Mental Health Hospital .

Implementation Phase ; The intervention was carried out for patient in group discussion according to the session, different methods of teaching were used including: Group discussions, interactive lectures, demonstration and re demonstration .Visual , audio and audio visual material were used as teaching aids Teaching sessions were as follows:

\section{1- The First Session ( Introductory}

Session ) The researcher introduced herself for the patients, introduce patients to each other and give each patient the opportunity to talk about himself after explanation of the aim of the study and notifying them about the schedule of the program .

\section{2- The Second Session}

The researcher interviewed the patients and give him an opportunity to identify the meaning of spirituality, benefits of spirituality and examples about spiritual practices.

\section{3- The Third Session}

This session focused on providing the patients with an opportunity to explore religious and spiritual issues by asking each patient some questions in relation to 
their religious and spiritual issues in the past, present and future life .

\section{4- The Fourth Session}

This session focused on helping the patient to participate in spiritual practices as spend time in meditation. The researcher inform the patient about the meaning of meditation, characteristics of meditation, steps of implementing meditation, and what must be avoided when implementing meditation .

\section{5- The Fifth Session}

This session focused on educating the patient about forgiveness, inform each patient about the meaning of forgiveness, its importance, the role of forgiveness in Islamic religion( all study group Muslim), and the 12 steps of forgiveness .

\section{6- The Sixth Session}

firstly this session focused on the praying , Secondary this session focused on helping the patient to know about scripture neither reading the holly Quran nor listening to another patient when reading holly Quran or listening to registered Quran . Thirdly this session focused on introducing audio visual material as videos about religious topics .

\section{7- The Seventh Session}

This session focused on helping the patient to participate in drawing, and to practice listening to soft music.

\section{8- The Eighth Session}

This session focused on helping the patients to perform exercises such as deep breathing exercise and muscle relaxation technique.

\section{9- The Ninth Session}

The researcher review the topics covered by the group and solicit feedback from the group members about the program.

Evaluation Phase The evaluation of the implemented program was done by: reapplying of tool II (DSES ) and tool III ( WHO QOL scale ) as follows: Immediately after the implementation of the program, one months later after the program implementation, three months after the implementation of the .

\section{Statistical Analysis}

\section{Data analysis:}

Data were collected over a period of 8 months starting from January 2015 to August 2015 . Data were then categorized and coded. Statistical presentation and analysis of the study was conducted, using the analysis of variance [ANOVA], Chisquare and tests by SPSS v20. 


\section{Results}

As regard the socio-demographic characteristics of the studied patients, the study shows that most of the patients were male $(74 \%)$, their mean age was $42.6 \pm$ 12.7 years , $48 \%$ of them were single and $32 \%$ were married. In relation to the residence of the studied patients, it shows that $60 \%$ of the patients were living in rural areas and $54 \%$ of them live with their families . Concerning the patients' income , $56 \%$ of the studied patients reported that it was not enough .

Concerning the patients' level of education , $28 \%$ of the studied patients were either illiterates or read and write, and $26 \%$ had secondary education and the same percentage also reported having university education . Regarding to the occupation of the studied patients, $32 \%$ of them were manual workers , $28 \%$ were unemployed , $26 \%$ were employees and only $14 \%$ of

them were retired .

Table (1) shows the percentage distribution of the studied patients according to their clinical data. It shows that $54 \%$ of the studied patients had schizophrenia and 30\% had depression. Regarding the duration of the illness , 38
$\%$ of the studied patients had the disease from 10 to 25 years, and $26 \%$ of them had the disease from one to less than 5 years with a mean of $11.7 \pm 6.5$ years . Regarding the number of previous hospitalization of the studied patients $44 \%$ were admitted three times and more, while $24 \%$ of the studied patients were not previously admitted to the hospital .

Table (2) Represent percentage distribution of the studied patients according to their total score of the spirituality through the study phases . It is observed that only $8 \%$ of the studied patients gained high spirituality score pre the program application. This percentage improved immediately post the program application to reach $62 \%$ of the studied patients and $70 \%$ of them at one month post the program application, then decreased to $44 \%$ three months post the program application.

There is statistically significant differences between the preprogram application phase and other phases of the program (immediately, one month and three months post the program application $(\mathrm{x} 2=$ $34.813,, 42.200$ and 21.991 respectively) and $\mathrm{p}$ value $<0.001 *$.

Table (3) Represent percentage distribution of the studied patients 
according to their total score of the quality of life through the study phases. The table illustrate that the total score of quality of life for $68 \%$ of the studied patients was low at preprogram application, while immediately post the program application the total score of quality of life improved as more than one third of them ( $38 \%$ ) had high quality of life score. This percentage increased to $62 \%$ of them one month post program, then decreased to $54 \%$ of them three months post program application. There were statistically significant difference between the preprogram application phase and other phases of the program (immediately, one month and three months post the program application ) as $\mathrm{x} 2=(32.534,37.985$, and 35.291 respectively ) and p value $<0.001 *$.

Table (4) shows that there is significant statistically positive correlation between the total score of QOL and total score of spirituality among the studied patients pre , immediately, one month and three months post application of the program , as $\mathrm{r}=(0.537,0.661,0.982$ and 0.830 respectively $)$ and $\mathrm{p}-$ value $=(0.047$, $0.034,<0.001$ and 0.005 respectively)

Table (5) Represent the relationship between socio demographic characteristics of the studied patients and their total score of quality of life through the study phases . The table shows that there is statistically significant relationship between quality of life and age of the studied patients as of those who gained high score immediately post program application were from the age group 30 to less than 40 years. $\left(\mathrm{x}^{2}=\right.$ 18.530 and $\mathrm{p}$ value $=0.005)$.

The table reflect that there is a statistically significant relationship between the total score of quality of life and sex of the studied patients, as it was observed that the majority of the studied patients $94.7 \%$ who had high quality of life immediately post the program application were males $\left(x^{2}=12.132\right.$ and $p$ - value $\left.=0.002\right)$, and $80.6 \%$ of the studied patients who had high quality of life one month post program application were males $\left(\mathrm{x}^{2}=\right.$ 9.778 and $\mathrm{p}$ - value $=0.008$ )

This table also demonstrate that there is a statistically significant relationship between the quality of life of the studied patients and their marital status as it was observed that ( $60 \%$ ) of the studied patients who had high quality of life immediately post program application were married $\left(\mathrm{x}^{2}=18.787\right.$ and $\mathrm{p}$ - value $=$ 0.016) and $50 \%$ of them who had high quality of life three month post program 
application were married ( $\mathrm{x}^{2}=17.034$ and $\mathrm{p}$ - value $=0.030$ )

This table illustrate that there is a statistically significant relationship between the quality of life of the studied patients and their income at one month post program application as it was observed that $64.5 \%$ of the studied patients who had high quality of life had enough income $\left(\mathrm{x}^{2}=17.705\right.$ and $\mathrm{p}$ - value $=$ 0.002 ).

Table (6) Represent the relationship between diagnosis of the studied patients and their total score of quality of life through the study phases, it was observed that there was no statistical significant relationship between diagnosis of the studied patients and their score of quality of life except immediately post program application where $52.6 \%$ of the studied patients who had significantly high scores of quality of life had diagnosis of depression $\left(\mathrm{x}^{2}=15.222\right.$ and $\mathrm{p}$ - value $=$ 0.019) .

Table (7) Illustrate that there is statistically significant relationship between duration of the illness of the studied patients and their total score of spirituality as immediately post program application more than one third of the studied patients $(38.7 \%)$ of those who had high spirituality score had the disease from 1to less than 6 years $\left(\mathrm{x}^{2}=13.040\right.$ and $p$ - value $=0.042$ ) , and more than half of the studied patients $54.6 \%$ of those who had high quality of life score at the three months post the program application had the disease more than 10 years $\left(\mathrm{x}^{2}=16.679\right.$ and $\mathrm{p}$ - value $=$ $0.011)$.

Table (1): Percentage distribution of the studied patients according to their clinical data .

\section{Clinical characteristics}

The studied patients $(n=50)$ 


\begin{tabular}{|c|c|c|}
\hline & $\mathbf{N}$ & $\%$ \\
\hline \multicolumn{3}{|l|}{ Diagnosis: } \\
\hline Schizophrenia & 27 & 54.0 \\
\hline Depression & 15 & 30.0 \\
\hline Bipolar disorder & 6 & 12.0 \\
\hline Addiction & 2 & 4.0 \\
\hline \multicolumn{3}{|l|}{ Duration of the disease : } \\
\hline$<1$ year & 8 & 16.0 \\
\hline $1-$ & 13 & 26.0 \\
\hline $5-$ & 10 & 20.0 \\
\hline $10-25$ & 19 & 38.0 \\
\hline \multirow{2}{*}{\multicolumn{3}{|c|}{$\begin{array}{l}\text { Range } \\
\text { Mean } \pm \text { SD }\end{array}$}} \\
\hline & & \\
\hline & \multicolumn{2}{|c|}{$\begin{array}{c}8 \text { month }-25 \text { years } \\
11.7 \pm 6.5\end{array}$} \\
\hline \multicolumn{3}{|l|}{ Number of hospital admissions: } \\
\hline No previous hospitalization & 12 & 24.0 \\
\hline One time & 8 & 16.0 \\
\hline Two times & 8 & 16.0 \\
\hline Three times and more & 22 & 44.0 \\
\hline
\end{tabular}

Table (2) Percentage distribution of the studied patients according to their total score of the spirituality through the study phases $(n=50)$ :

\begin{tabular}{|c|c|c|c|c|c|c|c|c|}
\hline \multirow{3}{*}{$\begin{array}{c}\text { Total score } \\
\text { of the spirituality }\end{array}$} & \multicolumn{8}{|c|}{ The program phases } \\
\hline & \multicolumn{2}{|c|}{$\begin{array}{l}\text { Pre the } \\
\text { program }\end{array}$} & \multicolumn{2}{|c|}{$\begin{array}{l}\text { Immediately } \\
\text { post program }\end{array}$} & \multicolumn{2}{|c|}{$\begin{array}{l}\text { one month } \\
\text { post } \\
\text { program }\end{array}$} & \multicolumn{2}{|c|}{$\begin{array}{c}3 \text { months } \\
\text { post program }\end{array}$} \\
\hline & No & & No & $\%$ & N0 & $\%$ & No & $\%$ \\
\hline Low & & 52.0 & 6 & 12.0 & & 10.0 & 8 & 16.0 \\
\hline Moderate & 20 & 40.0 & 13 & 26.0 & 10 & 20.0 & 20 & 40.0 \\
\hline High & 4 & 8.0 & 31 & 62.0 & 35 & 70.0 & 22 & 44.0 \\
\hline $\begin{array}{l}\text { Pre the program \& } \\
\text { immediately post program } \\
\text { application }\end{array}$ & \multicolumn{8}{|c|}{$\begin{array}{c}\mathrm{x}^{2}=34.813 \\
\mathrm{P}=<0.001 *\end{array}$} \\
\hline $\begin{array}{l}\text { Pre the program \& one } \\
\text { month post program } \\
\text { application }\end{array}$ & \multicolumn{8}{|c|}{$\begin{array}{l}\mathrm{x}^{2}=42.200 \\
\mathrm{P}=<0.001 *\end{array}$} \\
\hline $\begin{array}{l}\text { Pre the program \& three } \\
\text { month post program } \\
\text { application }\end{array}$ & \multicolumn{8}{|c|}{$\begin{array}{c}x^{2} 21.991 \\
p=<0.001 *\end{array}$} \\
\hline
\end{tabular}


Table (3) Percentage distribution of the studied patients according to their total score of the quality of life through the study phases $(n=50)$ :

\begin{tabular}{|c|c|c|c|c|c|c|c|}
\hline \multirow{3}{*}{$\begin{array}{c}\text { Total score of the quality of } \\
\text { life }\end{array}$} & \multicolumn{7}{|c|}{ The program phases } \\
\hline & \multicolumn{2}{|c|}{$\begin{array}{c}\text { Pre the } \\
\text { program }\end{array}$} & \multicolumn{2}{|c|}{$\begin{array}{l}\text { Immediately } \\
\text { post program } \\
\text { application }\end{array}$} & $\begin{array}{c}\text { one month } \\
\text { post } \\
\text { program } \\
\text { application }\end{array}$ & \multicolumn{2}{|c|}{$\begin{array}{c}3 \text { months } \\
\text { post program } \\
\text { application }\end{array}$} \\
\hline & No & & No & $\%$ & No $\%$ & No & $\%$ \\
\hline Low & & 68.0 & 5 & 10.0 & $\begin{array}{ll}9 & 18.0 \\
\end{array}$ & 7 & 14.0 \\
\hline Moderate & 13 & 26.0 & 26 & 52.0 & $10 \quad 20.0$ & 16 & 32.0 \\
\hline High & 3 & 6.0 & 19 & 38.0 & 62.0 & 27 & 54.0 \\
\hline $\begin{array}{l}\text { Pre the program \& } \\
\text { immediately post program } \\
\text { application }\end{array}$ & \multicolumn{7}{|c|}{$\begin{array}{l}\mathbf{x}^{2}=32.534 \\
\mathrm{p}=<0.001 *\end{array}$} \\
\hline $\begin{array}{l}\text { Pre the program \& one } \\
\text { month post program } \\
\text { application }\end{array}$ & \multicolumn{7}{|c|}{$\begin{array}{r}\mathbf{x}^{2}=37.985 \\
\mathrm{p}=<0.001 *\end{array}$} \\
\hline $\begin{array}{l}\text { Pre the program \& three } \\
\text { month post program } \\
\text { application }\end{array}$ & \multicolumn{7}{|c|}{$\begin{array}{l}\mathbf{x}^{2}=35.291 \\
\mathrm{p}=<0.001 *\end{array}$} \\
\hline
\end{tabular}

Table (4) Correlation between total score of spirituality and quality of life among the studied patients through the study phases $(n=50)$ :

\begin{tabular}{|l|c|c|}
\hline \multirow{2}{*}{ Total score of the quality of life } & \multicolumn{2}{|l|}{ Total score of the spirituality } \\
\cline { 2 - 3 } & $\mathrm{r}$ & $\mathrm{P}$ - value \\
\hline Pre the program & 0.537 & $0.047^{*}$ \\
\hline Immediately post program & 0.661 & $0.034^{*}$ \\
\hline One month post program & 0.982 & $<0.001^{*}$ \\
\hline Three months post the program & 0.830 & $0.005^{*}$ \\
\hline
\end{tabular}

Significant at $p<0.0$ 
Tanta Scientific Nursing Journal

Table (5 ) Relationship between socio demographic characteristics of the studied patients and their total score of quality of life through the study phases $(\mathbf{n}=50)$ :

\begin{tabular}{|c|c|c|c|c|c|c|c|c|c|c|c|c|}
\hline \multirow[t]{3}{*}{$\begin{array}{l}\text { Total score of quality } \\
\text { of life }\end{array}$} & \multicolumn{3}{|c|}{ Pre the program application } & \multicolumn{3}{|c|}{$\begin{array}{c}\text { Immediately post } \\
\text { program application }\end{array}$} & \multicolumn{3}{|c|}{$\begin{array}{c}\text { one month post program } \\
\text { application }\end{array}$} & \multicolumn{3}{|c|}{$\begin{array}{c}\text { Three months post program } \\
\text { application }\end{array}$} \\
\hline & Low & $\begin{array}{c}\text { Mode } \\
\text { rate }\end{array}$ & High & Low & $\begin{array}{l}\text { Modera } \\
\text { te }\end{array}$ & High & Low & $\begin{array}{c}\text { Mode } \\
\text { rate } \\
\end{array}$ & High & Low & \begin{tabular}{|c|} 
Modera \\
te
\end{tabular} & High \\
\hline & $\begin{array}{l}\text { N0 \% } \\
\mathrm{n}=34\end{array}$ & $\begin{array}{l}\text { No \% } \\
\text { n= } 13\end{array}$ & $\begin{array}{c}\text { N0 \% } \\
\text { n= } 3\end{array}$ & $\begin{array}{c}\text { N0 \% } \\
\text { n= } 5\end{array}$ & $\begin{array}{l}\text { N0 \% } \\
\mathrm{n}=26\end{array}$ & $\begin{array}{l}\text { N0 \% } \\
\text { n=19 }\end{array}$ & $\begin{array}{c}\mathrm{N} 0 \% \\
\mathrm{n}=9\end{array}$ & $\begin{array}{r}\text { No \% } \\
\text { n=10 }\end{array}$ & $\begin{array}{l}\text { No \% } \\
\text { n= } 31\end{array}$ & $\begin{array}{l}\mathrm{N} \% \\
\mathrm{n}=7\end{array}$ & $\begin{array}{l}\mathrm{N} \% \\
\mathrm{n}=16\end{array}$ & $\begin{array}{l}\mathbf{N} \% \\
\mathbf{n}=\mathbf{2 7}\end{array}$ \\
\hline \multicolumn{13}{|l|}{ Age in years } \\
\hline $20-$ & 1132.3 & 538.4 & 133.3 & 240.0 & 934.6 & 631.6 & 333.3 & 440.0 & 1032.2 & 00.0 & $\begin{array}{ll}6 & 37.5 \\
\end{array}$ & 1140.8 \\
\hline 30 - & 617.6 & 323.0 & 0 0.0 & $\begin{array}{ll}0 & 0.0\end{array}$ & 13.9 & 842.1 & 222.2 & 110.0 & 619.4 & 228.6 & $\begin{array}{ll}3 & 18.8\end{array}$ & 414.8 \\
\hline $40-$ & 1338.2 & 323.0 & 266.7 & 120.0 & 1453.9 & 315.8 & 333.3 & 220.0 & 1341.9 & 457.1 & $\begin{array}{ll}6 & 37.5\end{array}$ & $8 \quad 29.6$ \\
\hline $50-65$ & 411.8 & 215.4 & 0 0.0 & 240.0 & 27.6 & $\begin{array}{l}2 \\
10.5\end{array}$ & 111.1 & $3 \mathbf{3 0 . 0}$ & 26.5 & 114.3 & 16.2 & 414.8 \\
\hline $\mathbf{X}^{2}-\mathbf{p}$ & \multicolumn{3}{|c|}{$3.361 \quad(0.910)$} & \multicolumn{3}{|c|}{$18.530 \quad(0.005 *)$} & \multicolumn{3}{|c|}{$5.913 \quad(0.657)$} & \multicolumn{3}{|c|}{$7.437 \quad(0.490)$} \\
\hline \multicolumn{13}{|l|}{ Sex } \\
\hline Male & 2573.5 & $\begin{array}{l}10 \\
76.9\end{array}$ & 266.7 & 120.0 & 1869.2 & $\begin{array}{l}18 \\
94.7\end{array}$ & 333.3 & $\begin{array}{l}9 \\
90.0\end{array}$ & 2580.6 & $\begin{array}{l}7 \\
100.0\end{array}$ & 1168.7 & $\begin{array}{ll}19 & 70.4\end{array}$ \\
\hline Female & 926.5 & 323.1 & 133.3 & 480.0 & 830.8 & 15.3 & 666.7 & $\begin{array}{ll}10.0 \\
\end{array}$ & $\begin{array}{ll}6 & 19.4\end{array}$ & $\begin{array}{ll}0 & 0.0\end{array}$ & 531.3 & 829.6 \\
\hline
\end{tabular}

Significant at $\mathrm{p}<0.05$ 
Tanta Scientific Nursing Journal

\section{Continue table ( 5 )}

\begin{tabular}{|c|c|c|c|c|c|c|c|c|c|c|c|c|}
\hline$X^{2}-p$ & \multicolumn{3}{|c|}{$0.145 \quad(0.930)$} & \multicolumn{3}{|c|}{$12.132(0.002 *)$} & \multicolumn{3}{|c|}{$9.778(0.008 *)$} & \multicolumn{3}{|c|}{$2.874 \quad(0.238)$} \\
\hline \multicolumn{13}{|c|}{ Marital status } \\
\hline Single & 1751.5 & 753.9 & 00.0 & 360.0 & 1456.0 & 735.0 & 450.0 & 763.6 & 1341.9 & 571.4 & \begin{tabular}{|l|l|}
8 & 53.3
\end{tabular} & $\begin{array}{ll}11 & 39.3\end{array}$ \\
\hline Married & 927.3 & 430.7 & 375.0 & $\begin{array}{ll}0 & 0.0\end{array}$ & 416.0 & 1260.0 & 225.0 & $\begin{array}{ll}1 & 9.1\end{array}$ & 1341.9 & 114.3 & $\begin{array}{ll}1 & 6.7\end{array}$ & $14 \quad 50.0$ \\
\hline Divorced & 618.2 & 17.7 & $\begin{array}{ll}\mathbf{0} & \mathbf{0 . 0}\end{array}$ & $\begin{array}{ll}2 & 40.0\end{array}$ & $\begin{array}{ll}5 & 20.0\end{array}$ & 0 0.0 & 225.0 & 218.2 & $\begin{array}{ll}3 & 9.7\end{array}$ & $\begin{array}{ll}1 & 14.3\end{array}$ & 426.7 & $\begin{array}{ll}2 & 7.1\end{array}$ \\
\hline Widow & 13.0 & 17.7 & 125.0 & $\begin{array}{ll}\mathbf{0} & \mathbf{0 . 0}\end{array}$ & $\begin{array}{ll}28.0 \\
\end{array}$ & 15.0 & $\begin{array}{ll}0 & 0.0\end{array}$ & 19.1 & 25.5 & $\begin{array}{ll}0 & 0.0\end{array}$ & $\begin{array}{ll}2 & 13.3\end{array}$ & 13.6 \\
\hline$X^{2}-p$ & \multicolumn{3}{|c|}{$8.468 \quad(0.389)$} & \multicolumn{3}{|c|}{$18.787(0.016 *)$} & \multicolumn{3}{|c|}{$10.894(0.208)$} & \multicolumn{3}{|c|}{$17.034(0.030 *)$} \\
\hline \multicolumn{13}{|l|}{ Income } \\
\hline Not enough & 1955.9 & 861.5 & 133.3 & 240.0 & $15 \quad 57.7$ & 1157.9 & $\begin{array}{ll}9 & 100.0\end{array}$ & 880.0 & 1135.5 & 342.9 & 956.2 & $16 \quad 59.2$ \\
\hline Enough & 1544.1 & $\begin{array}{ll}5 & 38.5\end{array}$ & $\begin{array}{ll}2 & 66.7\end{array}$ & 360.0 & 1142.3 & $\begin{array}{ll}8 & 42.1\end{array}$ & $\begin{array}{ll}0 & 0.0\end{array}$ & 220.0 & 2064.5 & $\begin{array}{ll}457.1 \\
\end{array}$ & 743.8 & 1140.8 \\
\hline$X^{2}-p$ & \multicolumn{3}{|c|}{$0.788 \quad(0.674)$} & \multicolumn{3}{|c|}{$0.577(0.749)$} & \multicolumn{3}{|c|}{$17.705(0.002 *)$} & \multicolumn{3}{|c|}{$0.608 \quad(0.738)$} \\
\hline
\end{tabular}

Significant at $p<0.05$ 
Table (6 ) Relationship between diagnosis of the studied patients and their total score of quality of life through the study phases $(\mathbf{n}=\mathbf{5 0})$ :

\begin{tabular}{|c|c|c|c|c|c|c|c|c|c|c|c|c|}
\hline \multirow[t]{3}{*}{$\begin{array}{l}\text { Total quality of } \\
\text { life }\end{array}$} & \multicolumn{3}{|c|}{ Pre the program application } & \multicolumn{3}{|c|}{$\begin{array}{l}\text { Immediately post program } \\
\text { application }\end{array}$} & \multicolumn{3}{|c|}{$\begin{array}{c}\text { one month post program } \\
\text { application }\end{array}$} & \multicolumn{3}{|c|}{$\begin{array}{c}\text { Three months post program } \\
\text { application }\end{array}$} \\
\hline & Low & Moderate & High & Low & Moderate & High & Low & Moderate & High & Low & Moderate & High \\
\hline & $\begin{array}{l}\mathbf{N} \% \\
\mathbf{n}=\mathbf{3 4}\end{array}$ & $\begin{array}{l}\mathbf{N} \% \\
\mathrm{n}=\mathbf{1 3}\end{array}$ & $\begin{array}{l}\mathbf{N} \% \\
\mathbf{n}=\mathbf{3}\end{array}$ & $\begin{array}{l}\mathbf{N} \% \\
\mathbf{n}=5\end{array}$ & $\begin{array}{l}\mathbf{N} \% \\
\mathrm{n}=\mathbf{2 6}\end{array}$ & $\begin{array}{l}\mathbf{N} \% \\
\mathbf{n}=19\end{array}$ & $\begin{array}{l}\mathbf{N} \% \\
\mathbf{n}=9\end{array}$ & $\begin{array}{l}\mathbf{N} \% \\
\mathrm{n}=\mathbf{1 0}\end{array}$ & $\begin{array}{l}\mathbf{N} \% \\
\mathrm{n}=31\end{array}$ & $\begin{array}{l}\mathbf{N} \% \\
\mathbf{n}=7\end{array}$ & $\begin{array}{l}\mathbf{N} \% \\
\mathrm{n}=16\end{array}$ & $\begin{array}{l}\mathbf{N} \% \\
\mathbf{n}=27\end{array}$ \\
\hline \multicolumn{13}{|l|}{ Diagnosis } \\
\hline Schizophrenia & $\begin{array}{ll}18 & 52.9\end{array}$ & $\begin{array}{ll}8 & 61.5\end{array}$ & 133.3 & $\begin{array}{l}5 \\
100.0\end{array}$ & 1869.3 & $4 \quad 21.1$ & $4 \quad 44.4$ & $7 \mathbf{7 0 . 0}$ & 1651.6 & 571.4 & 743.7 & 1555.6 \\
\hline Depression & 1132.4 & $\begin{array}{ll}3 & 23.1\end{array}$ & 133.3 & $\begin{array}{ll}\mathbf{0} & \mathbf{0 . 0}\end{array}$ & $\begin{array}{ll}5 & 19.2\end{array}$ & 1052.6 & $2 \quad 22.2$ & $\begin{array}{ll}2 & 20.0\end{array}$ & 1135.5 & $\begin{array}{ll}1 & 14.3\end{array}$ & $7 \quad 43.7$ & 725.9 \\
\hline $\begin{array}{l}\text { Bipolar } \\
\text { disorder }\end{array}$ & $\begin{array}{ll}3 & 8.8\end{array}$ & $\begin{array}{ll}2 & 15.4\end{array}$ & 133.3 & $\begin{array}{ll}\mathbf{0} & \mathbf{0 . 0}\end{array}$ & $\begin{array}{ll}2 & 7.7\end{array}$ & 421.1 & $\begin{array}{ll}2 & 22.2\end{array}$ & $\begin{array}{ll}1 & 10.0\end{array}$ & $\begin{array}{ll}3 & 9.7\end{array}$ & 00.0 & 212.6 & $4 \quad 14.9$ \\
\hline Addiction & 25.9 & $\begin{array}{ll}\mathbf{0} & \mathbf{0 . 0}\end{array}$ & 00.0 & $\begin{array}{ll}\mathbf{0} & \mathbf{0 . 0}\end{array}$ & 13.8 & 15.2 & 111.2 & $\begin{array}{ll} & \mathbf{0 . 0}\end{array}$ & $\begin{array}{ll}1 & 3.2\end{array}$ & 114.3 & 00.0 & $\begin{array}{ll}1 & 3.7\end{array}$ \\
\hline$X^{2}-p$ & \multicolumn{3}{|c|}{$3.152(0.790)$} & \multicolumn{3}{|c|}{$15.222 \quad(0.019 *)$} & \multicolumn{3}{|c|}{$4.025 \quad(0.673)$} & \multicolumn{3}{|c|}{$5.970 \quad(0.427)$} \\
\hline
\end{tabular}


Tanta Scientific Nursing Journal

Table (7 ) Relationship between duration of illness of the studied patients and their total score of spirituality through the study phases $(n=50)$ :

\begin{tabular}{|c|c|c|c|c|c|c|c|c|c|c|c|c|}
\hline \multirow[t]{3}{*}{$\begin{array}{l}\text { Total score of } \\
\text { spirituality }\end{array}$} & \multicolumn{3}{|c|}{ Pre the program application } & \multicolumn{3}{|c|}{$\begin{array}{l}\text { Immediately post the program } \\
\text { application }\end{array}$} & \multicolumn{3}{|c|}{$\begin{array}{c}\text { one month post the program } \\
\text { application }\end{array}$} & \multicolumn{3}{|c|}{$\begin{array}{l}\text { Three months post the } \\
\text { program application }\end{array}$} \\
\hline & Low & Moderate & High & Low & Moderate & High & Low & Moderate & High & Low & Moderate & High \\
\hline & $\begin{array}{l}N \% \\
n=24\end{array}$ & $\begin{array}{l}\mathbf{N} \% \\
\mathbf{n}=\mathbf{2 0}\end{array}$ & $\begin{array}{l}\mathbf{N} \% \\
\mathrm{n}=4\end{array}$ & $\begin{array}{l}\mathbf{N} \% \\
\mathrm{n}=6\end{array}$ & $\begin{array}{l}\mathbf{N} \% \\
\mathrm{n}=13\end{array}$ & $\begin{array}{l}\mathbf{N} \% \\
\mathbf{n}=31\end{array}$ & $\begin{array}{l}\mathbf{N} \% \\
\mathrm{n}=5\end{array}$ & $\begin{array}{l}\mathbf{N} \% \\
\mathrm{n}=10\end{array}$ & $\begin{array}{l}\mathbf{N} \% \\
\mathbf{n}=30\end{array}$ & $\begin{array}{l}\mathbf{N} \% \\
\mathrm{n}=8\end{array}$ & $\begin{array}{l}\mathbf{N} \% \\
\mathbf{n}=\mathbf{2 0}\end{array}$ & $\begin{array}{l}\mathbf{N} \% \\
\mathrm{n}=\mathbf{2 2}\end{array}$ \\
\hline
\end{tabular}

Duration of the illness (years):

\begin{tabular}{|c|c|c|c|c|c|c|c|c|c|c|c|c|}
\hline $\begin{array}{l}\text { Less than } 1 \\
\text { year }\end{array}$ & 415.4 & 420.0 & 10.0 & 00.0 & 430.8 & 412.9 & 120.0 & 220.0 & $\begin{array}{ll}5 & 14.3\end{array}$ & 450.0 & 210.0 & $\begin{array}{ll}2 & 9.1\end{array}$ \\
\hline 1- & $\begin{array}{ll}8 & 30.8 \\
\end{array}$ & $\begin{array}{ll}5 & 25.0\end{array}$ & $\begin{array}{ll}\mathbf{0} & \mathbf{0 . 0}\end{array}$ & $\begin{array}{ll}\mathbf{0} & \mathbf{0 . 0}\end{array}$ & 17.7 & 1238.7 & 120.0 & 440.0 & $\begin{array}{ll}8 & 22.9\end{array}$ & 450.0 & $\begin{array}{ll}6 & 30.0\end{array}$ & $\begin{array}{ll}3 & 13.6\end{array}$ \\
\hline 6- & 623.0 & $\begin{array}{ll}3 & 15.0\end{array}$ & 125.0 & 116.7 & $\begin{array}{ll}2 & 15.4\end{array}$ & 722.6 & 240.0 & 110.0 & 720.0 & 00.0 & 525.0 & $\begin{array}{ll}5 & 22.7\end{array}$ \\
\hline $\begin{array}{l}\text { More than } 10 \\
\text { years }\end{array}$ & $\begin{array}{ll}8 & 30.8\end{array}$ & 840.0 & $\begin{array}{ll}3 & 75.0\end{array}$ & $\begin{array}{ll}5 & 83.3\end{array}$ & $\begin{array}{ll}6 & 46.1\end{array}$ & $\begin{array}{ll} & 25.8\end{array}$ & 120.0 & $\begin{array}{ll}3 & 30.0\end{array}$ & 1542.8 & $\begin{array}{ll}0 & 0.0\end{array}$ & 735.0 & 1254.6 \\
\hline$X^{2}-P$ & \multicolumn{3}{|c|}{$4.364 \quad(0.628)$} & \multicolumn{3}{|c|}{$13.040(0.042 *)$} & \multicolumn{3}{|c|}{$3.482 \quad(0.746)$} & \multicolumn{3}{|c|}{$16.679(0.011 *)$} \\
\hline
\end{tabular}

Significant at $\mathrm{p}<0.05$ 


\section{Discussion}

Spirituality can play an important role in helping people live with or recover from mental health problems. Spirituality is not tied to any particular religious belief or tradition. It can also help people to deal with mental distress or mental illness , and bring a feeling of being connected to something bigger than self and it can help people make sense of what they are experiencing ${ }^{(21)}$

The present study revealed that most of the patients were males, this may be due to the nature of availability of male patients during data collection phase as the number of hospitalized male patients were more than the female patients during this period . This may be due to the culture of rural people at Tanta city who do not prefer to hospitalize females in a psychiatric hospital unless it is extremely necessary .They usually prefer outpatient treatment and home care . These results were similar to those of the study done by Shalaby (2013) who found that $70 \%$ of patients were males (22) . This is in contrast with the study by Young K • ( 2012 ), about factors predicting overall life satisfaction for people with long-term mental illness who found that $62.2 \%$ of the patients were females ${ }^{(23) \text {. }}$
The present study revealed that more than half of the studied patients had schizophrenia (Table 1) .This may be attributed to that schizophrenia is more common in psychiatric hospital as a major psychiatric illness that needs hospitalization . In a study by Sharir D. et al , (2007) about social support and quality of life among psychiatric patients in residential homes, found that $38 \%$ of patients had schizophrenia ${ }^{(24)}$.

Regarding the total score of spirituality of the studied patients, the results of the present study showed that more than half of the studied patients had low total spirituality score pre the program application ( Table 2 ). This may be due to unawareness of the spiritual dimension in the hospital and not including spiritual assessment and intervention in the patient care plan .It was noticed that immediately and after one month application of the program, about two thirds of the patients gained high spiritual score. This indicates that the educational program had noticeable effect on the spirituality score of the studied patients e.g., help the patients to participate in spiritual practice as spend time in meditation, participate in reading and listening about scripture, perform praying according to patient's like either 
solitary or with a group, identify the meaning of some religious topics through watching religious video as there was no opportunity for attendance of religious leader to the hospital because the hospital policy not allow for that . It was observed that the score decreased after three months of the program application as less than half of patients had high spiritual score. This may be as the result of stoppage of the program and the hospital policy focused mainly on medical care not on the spiritual care . Furthermore, the numbers of social workers was not sufficient to provide spiritual care for each patient and they were not fully interested with spiritual considerations, but their emphasis was on provision of recreational therapy .

This result is supported by a study done by Hefti $R$.(2011), who applied program about integrating religion and spirituality into a mental health care setting, and found that more than $80 \%$ of the participants used religious beliefs or activities to cope with daily difficulties and religious or spiritual coping was an essential part of their coping behavior as religion provides patients with a framework to cope with disease - relate struggles and instilled hope, purpose, and meaning in their lives ${ }^{(25)}$.
Initially, within the field of psychiatric research, the principal focus of QOL assessment has been on the symptoms, impairments, and disabilities of severely mentally ill persons suffering from long term and disabling illnesses such as schizophrenia , chronic depression, manicdepressive illness, and severe personality disorders. The reason for this focus lied in considering general population measures of QOL insensitive to the issues faced by this disabled population ${ }^{(26)}$.

Recently, researchers have tried to identify those factors leading to better quality of life for people with severe mental illness. However, many research studies have focused on the negative impact of psychiatric symptoms on individual's quality of life. These research studies consistently report that quality of life are negatively affected by current psychiatric symptoms, especially symptoms of depression and anxiety, experienced by people with severe mental illness ${ }^{(27-30)}$ The results of the present study showed that the total score of quality of life for more than half of the studied patients were low at the pre program application (Table 3) . This may be due to the nature of their psychiatric illness and some socio demographic characteristics, as more than 
half of the studied patients were from rural area in which most people there were not be concerned about their mental health and wellness and lack the awareness about psychiatric diseases . Furthermore, about half of the studied patients reported that they did not have enough income, were singles, even their mean age was 42.6 years, hospitalized 3time and more . All these factors may be attributed to low quality of life for the studied patients . Immediately post program application the total score of quality of life improved as more than one third of them had high quality of life score. This percentage increased one month post the program as more than half of patients had high total score of QOL. This may be due to the effect of program which included educational sessions about spirituality, forgiveness and training sessions that focus on stress reduction techniques as meditation and training exercise as deep breathing exercises, yoga, muscle relaxation techniques. Then the percentage decreased three month post the program application. This highlights the need of the nursing and medical staff at the hospital to be more engaged in providing more time and effort with these patients to help them to express their feelings and concerns and to train them to practice some techniques for stress reduction. This is supported by a study done by Evans S . (2007), about quality of life impairment in schizophrenia, mood and anxiety disorder, found that people with severe mental illness are consistently found to have a lower quality of life than the general population without mental illness ${ }^{(31)}$. Furthermore, the quality of life of people with severe mental illness is found to be lower than people with common mental disorders ${ }^{(32)}$. Moreover, their lower level of quality of life is found to remain relatively stable throughout the course of mental illness ${ }^{(24)}$.

The present study showed that there were a significant statistically positive correlation between the total score of QOL and total score of spirituality among the studied patients pre, immediately, one month and three months post the application of the program ( Table 4). . This result is consistent with the study by Babaie $\mathbf{E}$ and Razeghi N . (2013), about comparing the effects of methadone maintenance treatment, therapeutic community, and residential rehabilitation on quality of life and mental health of drug addicts .The study found that engaging in religious activities and participating in religious ceremonies affects people's relationships with others, and can affect people's 
physical health and mental wellbeing. From these results, they recommended that religious and spiritual beliefs and practices can be assumed as supporting actors that bring hope and strength and give meaning to life. This, in turn, leads to a reduction in stress levels and improvements in people's quality of life ${ }^{(33)}$.

A study done by Abdullah C. (2012), about generalized anxiety disorder (GAD) from Islamic and western perspectives , found that full trust and complete reliance on God empowers a person to get relief from anxieties and fears in life ${ }^{(34)}$. Koenig et.al., (2001) , who analyzed the relationship of religion and health, found that if individuals have a meaningful life , they would be less vulnerable to develop anxieties and other psychopathologies. Moreover, a number of religious and spiritual activities are thought to encourage more frequent daily spiritual experience and these activities can then promote individual's quality of life ${ }^{(35)}$.

Concerning relationship between patient's age and total score of quality of life .The present study showed that there was statistically significant relationship between quality of life and age of the studied patients immediately post program application as about half of those who were from the age group 30 to less than 40 years had high quality of life ( Table 5 ). This may be attributed that patients in the young age have the energy and possess the ability to learn new things and respond quickly to stimulation and psychological counseling and that the illness did not become chronic, as it is easy to change certain patient's negative behavior. This is similar to a study done by Mohamed $\mathbf{S}$. (2010), found that younger patients were responding better and have high response to health wellness quality of life (HWQOL) immediately post program intervention (36). In contrast, a study done by Ahmed F. et al , (2004), about clinical characteristics and quality of life of schizophrenic patients at Alexandria, and studied the effects of age on the subjective QOL of people with severe and persistent mental illness. Findings demonstrated that age was systematically related to the degree of satisfaction as older participants were more satisfied than younger ones ${ }^{(37)}$. Concerning relationship between patient's sex and total score of quality of life it was observed that the majority of the studied patients who had high quality of life immediately post the program application were males, and this was also true one month post program application . This may be due to that male patients constituted nearly three quarters of the 
study sample and male patients generally have better social functioning, and more employment . In this respect a study done by Adep S. (2007), about the relation between quality of life and locus of control among schizophrenic out patients at Alexandria , found that QOL was consistently worse for women (38) .This come in contrast with Harfush S . (2014), who found that females had better QOL than male ${ }^{(39)}$.

The present study represented that there was a statistically significant relationship between the quality of life of the studied patients and their marital status as it was observed that more than half of the studied patients who had high quality of life immediately post program application were married and half of those who had high quality of life three month post program application were also married (Table 5) . This may be due to marriage help those people to have more social activities and support from their spouses and children while singles and divorced may suffer from loneliness which is associated with psychological problems .

These findings were similar to those of the study done by Akbiyik D et al. (2008), about quality of life of Turkish patients with depression in Ankara and in Berlin . The study found that recurrent depressive disorders (RDDs) have been observed to have significant marital maladjustment ${ }^{(40)}$. This is in contrast with the study of Subodh B. et al. , (2008), about psychosocial impact of dysthymia : a study among married patients., observed poor marital adjustment in depressive disorders but found no evidence of its link to psychosocial functioning or $\mathrm{QOL}^{(41)}$

Regarding the relationship between diagnosis of the studied patients and their total score of quality of life through the study phases, the present study showed that there was no statistical significant relationship between diagnosis of the studied patients and their score of quality of life except immediately post program application where more than half of the studied patients who had significantly high scores of quality of life had diagnosis of depression and schizophrenic patients had low scores of quality of life ( Table 6 ) - This may be due to the nature of schizophrenic disorders that have great disturbance of thought function and disharmony between patient's affect , thought and behaviors and it is difficult to enhance patient's response in this period. This is supported by a study of Mohamed S. (2011), reported that depressive and bipolar patients had better response to health wellness QOL (HWQOL) while 
schizophrenic patients had lower responses (36)

The present study showed that there was a statistically significant relationship between duration of the illness of the studied patients and their total score of spirituality as more than one third of the studied patients who had high spirituality score immediately after the program application had the disease from 1to less than 6 years, and more than half of the studied patients of those who had high quality of life score three months post the program application had the disease more than 10 years (Table 7 ). This may be due to when the length of period of disease increase, the patient become more close to Allah, coping positively with his disease and have greater well being. This result was supported by Shalaby (2013), who found that there was a positive significant statistical correlation between duration of mental illness and high score of spirituality (22) . In contrast Harfush S . (2014), reported that those who had a duration of illness less than 5 years had a better QOL than those whose duration of illness was more than 15 years ${ }^{(39)}$.

\section{Conclusion and Recommendations}

Based on the results of the present study, it can be conducted that there was marked improvement in the total score of patients as regard spirituality and QOL after application of psycho education program . Young aged, married males gained significantly higher scores of QOL and spirituality than others after implementation of the program. Furthermore, the QOL of the patients significantly correlated with their spirituality.

The followings are the main recommendations yielded by the present study :

1- Mental health professionals should adopt holistic treatment strategies that integrate spiritual factor into assessment and intervention.

2- Awareness and training programs about importance of spirituality for mentally ill patients should be implemented at psychiatric hospitals to all staff to encourage them to participate in the provision of spiritual care .

3- Psychosocial educational programs that involve social skill training, stress management, and vocational training should be provided during rehabilitation phase of hospitalized patients.

4- Recreational therapy should be included in the treatment plan for the patients to help them to use leisure 
times effectively and maintain activity of daily life .

\section{Reference}

1- Videbeck Sh . Psychiatric Mental Heath Nursing . $6^{\text {th }}$ ed . Philadelphia : Lippincott Williams and Wilkins Co., $2014 ; 107$.

2- Fortinash $\mathrm{K}$ and Holoday $\mathrm{F}$. Psychiatric Mental Heath Nursing . 4th ed., . Canada : Mosby Elsevier Co ., , $2008 ; 137-145$.

3- Weber S , Pargament K and Kunik M . Psychological distress among religious nonbelievers : A systematic review. Journal Religion Health , 2012; 51:72-86.

4- Gearing R, Alonzo D and Smolak A - Association of religion with delusions and hallucinations in the context of schizophrenia: implications for engagement and adherence. Schizophrenia Research . 2011; 126:150-163.

5- Konopack F and McAuley E . Efficacy-mediated effects of spirituality and physical activity on quality of life: A path analysis, health and quality of life outcomes . PMID , $2012 ; 10$ (1) : $226-283$.

6- Worret F . Psychiatric Nursing Care Plan . 5th ed. United States : Mosby El Sevier Co., 2007 ; 462.
7- Mohr W . Psychiatric Mental Heath Nursing , Evidence - Based Concepts , Skills, and Practices .7th ed. Philadelphia : Lippincott Williams and Wilkins Co., 2009 ; 117-127 .

8-Andrews $\mathrm{M}$ and Boyle J. Transcultural concepts in nursing care . 4th ed. Philadelphia : Lippincott Williams and Wilkins Co. , 2003;15

9- Koening G. Spirituality in Patient Care : Why, How, When, and What . 2nd ed. Philadelphia . Templeton Foundation . Press ; 2007;7-12 .

10- Narvaez M , Twamley W , McKibbin L , Heaton $\mathrm{K}$ and Patterson L. Subjective and objective quality of life in schizophrenia : Schizophrenia Research , 2008 ; 98 (1-3) : 201-208 .

11- Young W. Positive effects of spirituality on quality of life for people with severe mental illness. International Journal of Psychosocial Rehabilitation, 2012;16(2): 62-77.

12- Tolman $\mathrm{W}$ and Kurtz $\mathrm{M}$. Neurocognitive predictors of objective and subjective quality of life in individuals with schizophrenia: a meta-analytic investigation Schizophrenia Bulletin , 2012 ; 38 ( 2) : 304-315. 
13- Mohr S . Integration of spirituality and religion in the care of patients with severe mental disorders . Indian Journal Psychiatry 2013 ; 55 (205-214

14- Undrwood $\mathrm{L}$ and Teresi $\mathrm{J}$. The daily spiritual e Scale : Development, theoretical description, reliability, exploratory factor analysis and preliminary construct validity using health related data - Analysis of behavioral medicine . 2002 ; (24) :22-33.

15- The WHOQOL Group . Development of the world health organization WHOQOL - BREF quality of life assessment . Psycho med .2004; 28 (3) :551-558.

16-Green J , Gardner F and Sandra S . Healing of the soul : The role of spirituality in recovery from mental illness . International Journal of Psychosocial Rehabilitation , 2009; 13 (2) : 65-75 .

17-Andrade C . Prayer and healing : A medical and scientific perspective on randomized controlled trials . Indian Journal of Psychiatry , 2009 ; 51 (4) $: 247-253$.

18-Cabral P, Meyer $\mathrm{H}$ and Ames D . Effectiveness of yoga therapy as a complementary treatment for major psychiatric disorders : A meta - analysis Primary Care Companion for CNS Disorders . 2011; 13(4): 60-63.

19-Safara $M$ and Bhatia $M$. The Effect of spiritual music on health in different Religious . American Psychiatry Journal , 2014 ; 17 (1) : 22-27 .

20- Basu D. Quality of life issues in mental health care. Past, Present, Future . German Journal of Psychiatry , 2004 ; 7 (3) :35-43 .

21- Shives L . Basic Concepts of Psychiatric Mental Health Nursing . 8th ed Philadelphia : Lippincott Williams and Wilkins Co., 2012; $34-48$

22- Shalaby M . Relationship between spirituality and mental illness . Life Science Journal , 2014 ; 11 (2) :1-7

23- Young K . Factors predicting overall life satisfaction for People with longterm mental illness factors. International Journal of Psychosocial Rehabilitation , 2004 ; 9

(1) : 23-35.

24- Sharir D, Tanasescu M, Turbow D and Maman Y . Social support and quality of life among psychiatric patients in residential homes. International Journal of Psychosocial Rehabilitation, 2007 ; 11 (1) : 82-85.

25- Hefti R . Integrating religion and spirituality into mental health care . 
Psychiatry and Psychotherapy. www.mdpi .com /journal /religions . $2011 ; 2$ (2) : 611-627.

26-Chan W, Ungvari G, Shek T and Leung $\quad \mathbf{J}$. Hospital and community based care for patient with chronic schizophrenic in Hong Kong. Social Psychiatry and Psychiatric Epidemiology , 2003 ; 38 :196-203.

27 -Hansson L. Determinants of quality of life in people with severe mental illness. Acta Psychiatrica Scandinavica , 2006 ; 113 (429): 46-50.

28 -Langeland E , Wahl A , Kristoffersen $\mathrm{K}$, Nortvedt $\mathrm{M}$ \& Hanestad, B . Quality of life among Norwegians with chronic mental health problems living in the community versus the general population. Community Mental Health Journal , 2007 ; 43(4) : 321-339.

29- Norholm V, \& Bech P . Quality of life in schizophrenic patients: association with depressive symptoms. Nordic Journal of Psychiatry , 2006 ; $60(1): 32-37$.

30- Norman R Malla A, Mc Lean T, Voruganti L , Cortese L, Cheng $\mathrm{S}$ and Rickwoord A. The relationship of symptoms and level of functioning in schizophrenia to general wellbeing and quality of life scale.
Acta Psychiatric Scand, $2000 ; 102$ : 303-309.

31 -Evans S . Quality of life in mental health services. In ritner, M.S. \& Awad, G.A. (Eds.), Quality of Life Impairment in Schizophrenia , 2007.

32-Hill P . \& Paragament $K$. Advances in the conceptualization and measurement of religion and spirituality. American nursing journals , $2008 ; 5(1)$ : 3-17.

33- Babaie E, Razeghi N . Comparing the effects of methadone maintenance treatment, therapeutic community , and residential rehabilitation on quality of life and mental health of drug addicts . Addict Health , 2013 ;5 (12):16-20.

34-Abdullah C , Ismail H , Ahmad $\mathrm{N} \&$ Hissan, W. Generalized anxiety disorder from Islamic and western perspectives. World Journal of Islamic History and Civilization , $2012 ; 2$ : 44-52.

35-Koenig $\mathrm{H} \quad$, Mc Cullough $\mathrm{M}$ \& Larson D. Handbook of Religion and Health. Oxford University Press , 2001

36- Mohamed S . Effects of a trauma healing psycho - educational program on the wellness and quality of life of mentally ill patient. Doctoral thesis . 


\section{Tanta Scientific Nursing Journal}

Faculty of nursing . University of

Tanta , $2011: 70$-79 .

37-Ahmed F , Darweesh A , Maximios M and Sheref . A Clinical characteristics and quality of life of schizophrenic patients . 8th International Scientific Nursing Conferences . Alexandria , 2004.

38-Adep $\mathrm{S}$. The relation between quality of life and locus of control among schizophrenic out Patients. Unpublished Master Thesis . Faculty of Nursing . University of Alexandria , 2007 .

39- Harfush S . Impact of psycho educational program on the quality of life of Patients with schizophrenia . Doctoral thesis . Faculty of nursing . University of Tanta , 2014 .

40-Akbiyik D , Berksun O, Sumbuloglu V, Senturk V, Priebe S . Quality of life of Turkish patients with depression in ankara and in berlin. Eur Psychiatry, 2008 .23:S4YS9.

41- Subodh B , Avasthi A , Chakrabarti S . Psychosocial impact of dysthymia : A study among married patients . Journal Affect Disorders , 2008 . 109:199Y204. 